\title{
EKSPERIMENTASI MODEL PEMBELAJARAN APTITUDE TREATMENT INTRACTION (ATI) DENGAN PENDEKATAN CTL DITINJAU DARI KEDISIPLINAN BELAJAR MAHASISWA
}

\author{
Vera Dewi Susanti \\ Universitas PGRI Madiun \\ E-mail: vera.mathedu@unipma.ac.id
}

\begin{abstract}
The purpose of this research are: (1) To know which learning model give better learning to result between ATI teaching model with CTL, ATI and conventional approach, (2) to know which gives better learning result among students who have discipline of high, medium and low (3) To know whether there is interaction between learning model and learning discipline to mathematics learning achievement.The type of research is quasi experimental research (quasi experimental). Instruments used were mathematics achievement test, questionnaire, and documentation instrument. The data were analyzed by using twoway variance analysis with unequal cells.The conclusions of this study are (1) Learning outcomes with ATI learning model with CTL approach is better than ATI and conventional model, while the ATI learning model is better than conventional. (2) Students' learning outcomes with higher learning discipline are better than those with moderate and low self-discipline, while students with discipline are better than those with low discipline. (3) There is no interaction between the learning model and the discipline of learning on mathematics learning achievement
\end{abstract}

Keywords: ATI teaching model with CTL, ATI, conventional,discipline of learning

\section{PENDAHULUAN}

Pendidikan matematika memiliki peran yang sangat penting karena matematika adalah ilmu dari berbagai ilmu. Penguasaan terhadap matematika sangat diperlukan untuk menghadapi kemajuan pendidikan dan teknologi. Saat ini, matematika masih dianggap sebagai suatu bidang studi yang cukup sulit oleh siswa. Masih banyak siswa yang memperoleh hasil belajar yang kurang memuaskan pada bidang studi matematika. Banyak peserta didik yang mengalami kesulitan belajar dikarenakan adanya hambatan dalam mata pelajaran matematika, hal itu disebabkan rendahnya ketrampilan atau kekurangmampuan dirinya untuk memahami konsep-konsep matematika.

Sebelum mengajar di sekolahsekolah, calon guru perlu memahami betul apa yang akan disampaikan dalam pembelajaran yang akan diajarkan. Hal ini harus dimantapkan ketika calon guru tersebut masih dalam bangku perkuliahan, karena tidak semua mahasiswa memahami setiap matakuliah yang ditempuh, tidak menutup kemungkinan mahasiwa yang mengambil jurusan matematika belum tentu paham betul tentang matematika.

Salah satu faktor rendahnya pemahaman mahasiswa terhadap matakuliah yang ditempuh mungkin berasal dari faktor kualitas pembelajaran dosen dalam menyampaikan perkuliahan kurang menarik. Masih banyak dosen dalam memberi perkuliahan menggunakan model pembelajaran langsung. Dalam model ini lebih banyak menuntut keaktifan pengajar atau dosen dari pada mahasiswa sebagai peserta didik sehingga siswa kurang aktif dalam proses belajar mengajar. Selain itu dosen sering dalam memberikan 
perkuliahan dengan membagi materi perkuliahan kemudian meminta mahasiswa membagi beberapa kelompok untuk melakukan persentasi. Dalam hal ini, salah satu negatifnya adalah bagi sekelompok mahasiswa hanya mampu memahami materi yang akan dipersentasikan saja, materi dari kelompok lain kurang dipahami.

Susanti (2013) mengatakan seorang pendidik harus mempersiapkan model pembelajaran yang tepat dengan tujuan untuk mempermudah dalam pembelajaran matematika yang sesuai dengan karakteristik siswa dan pokok bahasan yang akan disampaikan, kemudian mengevaluasi hasil belajar dengan baik dan cermat sehingga proses pembelajaran dapat berjalan dengan optimal. Hal ini ditujukan supaya proses pembelajaran matematika lebih aktif, kreatif, efektif, dan menyenangkan. Alternatif lain yang dapat digunakan adalah dengan menggunakan model pembelajaran yaitu model pembelajaran kooperatif. Johnson (Isjoni, 2011:22) mengemukakan,

"Cooperanon means working
together to accomplish shared
goals. Within cooperative
activities individuals seek
autcomes that are beneficial to
all othergroups members.
Cooperative learning is the
instructional use of small group
that allows students to work
together to maximize their own
and each other as learning".
Pembelajaran kooperatif
mengandung arti bekerja bersama dalam mencapai tujuan bersama. Dalam kegiatan kooperatif siswa mencapai hasil yang menguntungkan bagi seluruh anggota kelompok. Belajar kooperatif adalah pemanfaatan kelompok kecil untuk memaksimalkan belajar mereka dan belajar anggota lainnya dalam kelompok itu. Prosedur pembelajaran kooperatif didesain untuk mengaktifkan siswa melalui inkuiri dan diskusi dalam kelompok kecil.

\section{Aptitude Treatment Intraction}

(ATI) merupakan sebuah konsep yang berisikan sejumlah strategi pembelajaran yang sedikit banyaknya efektif digunakan untuk siswa tertentu sesuai dengan karakteristik kemampuannya. Didasari oleh asumsi bahwa optimalisasi prestasi hasil belajar dapat dicapai melalui penyesuaian antara pembelajarandengan perbedaan kemampuan (aptitude) siswa.

Menurut Syafruddin Nurdin (dalam Oktalia, 2012: 3) secara substantif dan teoritik Aptitude Treatment Intraction (ATI) dapat diartikan sebagai suatu konsep/pendekatan yang memiliki sejumlah strategi pembelajaran yang efektif digunakan untuk individu tertentu sesuai dengan kemampuannya masing-masing. Selain itu, metode pembelajaran Aptitude Treatment Intraction (ATI) adalah sebuah pendekatan yang berusaha mencari dan menemukan perlakuan-perlakuan (treatment) yang cocok dengan perbedaan (aptitude) kemampuan siswa, yaitu perlakuan (treatments) yang secara optimal diterapkan untuk siswa yang berbeda tingkat kemampuannya. Menurut Caspin (2004), juga berpendapat bahwa model ATI ini terdiri dari tiga kata yaitu aptitude, treatment, interaction. Untuk mengetahui pengertian ATI secara keseluruhan perlu diketahui satu persatu. Aptitude adalah pengelompokan siswa sesuai dengan kemampuan yang dimiliki, treatment adalah perlakuan atau pembelajaran yang diberikan kepada siswa, dan interaction adalah pelayanan, interaksi atau bentuk motivasi yang diberikan kepada siswa. Sehingga dapat dikatakan bahwa model pembelajaran ATI terdiri 
dari tiga tahap yaitu Pengelompokkan (Aptitude), perlakuan (Treatment), dan pelayanan (Interaction).

Kelebihan model pembelajaran Aptitude Treatment Interaction antara lain (Setiani, 2013) : 1) Dapat meningkatkan motivasi belajar siswa, 2) Dapat meningkatkan pemahaman siswa terhadap materi pelajaran, 3) Guru dapat lebih memperhatikan kemampuan setiap siswa baik secara individu maupun kelompok, 4) Guru dapat memberikan treatment sesuai dengan kebutuhan siswa, 5) Siswa dapat mengoptimalkan prestasi belajarnya sesuai dengan kemampuannya.

Hanifah dan Suhana (2012: 67) mengatakan bahwa CTL (Contextual Teaching Learning) merupakan suatu proses pembelajaran holistik yang bertujuan untuk membelajarkan peserta didik dalam memahami bahan ajar secara bermakna (meaningfull) yang berkaitan dengan konteks kehidupan nyata, baik berkaitan dengan lingkungan pribadi, agama, sosial, ekonomi maupun stuktural. Sehingga peserta didik memperoleh ilmu pengetahuan dan ketrampilan yang dapat diaplikasikan dan ditransfer dari satu konteks permasalahan yang satu ke permasalahan yang lainnya.

$$
\text { Menurut Suyanto }
$$

Contextual Teaching and

Learning merupakan suatu pendekatan yang memungkinkan siswa untuk menguatkan, memperluas, dan menerapkan pengetahuan dan keterampilan yang mereka peroleh dalam berbagai macam mata pelajaran baik di sekolah maupun di luar sekolah Dalam konteks ini siswa perlu mengerti apa makna belajar, manfaatnya, dalam status apa mereka dan bagaimana mencapainya. Dengan ini siswa akan menyadari bahwa apa yang mereka pelajari berguna sebagai hidupnya nanti. Sehingga, akan membuat mereka memposisikan sebagai diri sendiri yang memerlukan suatu bekal yang bermanfaat untuk hidupnya nanti dan siswa akan berusaha untuk menggapainya. Menurut Nugroho (2017) juga mengatakan CTL merupakan strategi pembelajaran yang membantu guru mengaitkan antara materi yang diajarkan dengan situasi dunia nyata siswa dan mendorong siswa membuat hubungan antara pengetahuan yang dimilikinya dengan penerapannya sehingga pembelajaran semakin bermakna.

Selain penggunaan metode pembelajaran yang dimodifikasi, faktor lain yang mempengaruhi keberhasilan kegiatan belajar mengajar salah satunya adalah kedisiplinan belajar siswa. Kedisiplinan belajar pada diri siswa timbul dari dalam diri siswa itu sendiri tanpa adanya paksaan dari luar. Dengan adanya kedisiplinan siswa diharapkan nanti prestasi belajar matematika juga akan meningkat.

Tu'u (2004:32) menyebutkan bahwa disiplin muncul karena adanya kesadaran batin dan iman kepercayaan bahwa yang dilakukan itu baik dan bermanfaat bagi diri dan lingkungan. Sedangkan menurut Sinungan (Amriany, Probowati, dan Atmadji, 2004) disiplin adalah suatu sikap, tingkah laku atau perbuatan yang sesuai dengan peraturan, baik yang tertulis maupun tidak.

Kedisiplinan siswa dapat terlihat dalam perbuatan siswa untuk taat dan patuh terhadap peraturan yang ada serta kesadaran untuk mau melakukan tugas utamanya sebagai siswa yaitu belajar. Seorang siswa perlu memiliki kedisiplinan belajar agar dapat mencapai kesuksesan dalam belajar dan dapat memperoleh prestasi belajar yang tinggi. Kedisiplinan belajar dapat bervariasi antara siswa yang satu dengan siswa yang lain. Adanya 
perbedaan tingkat kedisiplinan belajar siswa dimungkinkan dapat menyebabkan perbedaan prestasi belajar siswa.

Tujuan dari penelitian ini adalah sebagai berikut :

1. Untuk mengetahui model pembelajaran mana yang memberikan hasil belajar yang lebih baik antara model pembelajaran ATI dengan CTL, ATI dan pendekatan konvensional.

2. untuk mengetahui manakah yang memberikan hasil belajar yang lebih baik di antara siswa yang memiliki disiplin tinggi, sedang dan rendah.

3. Untuk mengetahui apakah ada adalah interaksi antara model pembelajaran dan disiplin belajar dengan prestasi belajar matematika.

\section{METODE PENELITIAN}

Penelitian ini adalah penelitian eksperimental semu (quasi experimental). Menurut Budiyono (2009:121), keseluruhan pengamatan yang ingin diteliti, berhingga atau tak berhingga, membentuk apa yang disebut populasi (universum). Populasi dalam penelitian ini adalah mahasiswa semester VII pada pendidikan matematika di Universitas PGRI Madiun. Teknik pengambilan sampel yang digunakan dalam penelitian ini adalah stratified cluster random sampling. Adapun langkah-langkah yang ditempuh dalam pengambilan sampel adalah: dari populasi, seluruh mahasiswa kelas VII pendidikan matematika yang berjumlah 3 kelas, dibagi berdasarkan tiga kategori berdasakan nilai ujian akhir semester yaitu kategori tinggi, sedang dan rendah. Dalam penelitian ini ada dua variabel yaitu variabel terikat dan variabel bebas. Variabel terikatnya adalah prestasi belajar matematika sedangkan variabel bebasnya adalah kedisiplinan mahasiswa dan model pembelajaran. Penelitian ini menggunakan rancangan faktorial $3 \mathrm{x}$ 3 , dengan maksud untuk mengetahui pengaruh tiga variabel bebas terhadap variabel terikat. Metode pengumpulan data yang digunakan dalam penelitian ini adalah metode dokumentasi, metode tes dan metode angket.

Teknik analisis data dalam penelitian ini menggunakan (ANAVA) analisis variansi dua jalan dengan sel tak sama. Uji prasyarat yang dipakai dalam analisis data penelitian ini adalah uji normalitas dengan metode Lilliefors dan uji homogenitas dengan metode Barlett.

\section{HASIL PENELITIAN DAN PEMBAHASAN}

Data kelompok eksperimen I, kelompok eksperimen II dan kelompok eksperimen III selanjutnya dikategorikan dalam tiga kategori yaitu tinggi, sedang dan rendah. Berdasarkan hasil perhitungan, diperoleh:

Tabel 1. Hasil Pengelompokan Kedisiplinan Belajar Mahasiswa

\begin{tabular}{cccc}
\hline \multirow{2}{*}{ Model Pembelajaran } & \multicolumn{3}{c}{ Kategori } \\
\cline { 2 - 4 } & Tinggi & Sedang & Rendah \\
\hline ATI dengan CTL & 33 & 31 & 29 \\
\hline ATI & 30 & 34 & 31 \\
\hline Konvensional & 26 & 38 & 22 \\
\hline
\end{tabular}

Setelah data diolah diperoleh data prestasi belajar sebagai berikut: 
ISSN 2089-8703 (Print) Vol. 7, No. 1 (2018)

ISSN 2442-5419 (Online)

Tabel 2. Deskripsi Rataan Masing-masing Variabel

\begin{tabular}{|c|c|c|c|c|}
\hline \multirow{2}{*}{ Model Pembelajaran } & \multicolumn{3}{|c|}{ Kedisiplinan } & Rerata \\
\cline { 2 - 5 } ATI dengan CTL & Tinggi & Sedang & Rendah & \\
\hline ATI & 81,61 & 69,77 & 64,67 & 71,96 \\
\hline Konvensional & 77,75 & 61,20 & 53,87 & 64,04 \\
\hline Rerata & 64,67 & 55,90 & 51,12 & 57,17 \\
\hline & 75,64 & 62,21 & 56,80 & \\
\cline { 2 - 5 } & & & &
\end{tabular}

Hasil analisis uji normalitas dapat dilihat dalam Tabel 3 sebagai berikut.

Tabel 3. Tabel Uji Normalitas kemampuan Awal

\begin{tabular}{ccc}
\hline Uji normalitas & $\mathrm{L}_{\text {obs }}$ & $\mathrm{L}_{0,05 ; \mathrm{N}}$ \\
\hline ATI dengan CTL & 0,0704 & 0,09043 \\
\hline ATI & 0,0626 & 0,08372 \\
\hline Konvensional & 0,0804 & 0,09237 \\
\hline
\end{tabular}

Berdasarkan Tabel 3, untuk masingmasing sampel dari $\mathrm{L}_{\mathrm{obs}} \notin$ $D K=\left\{L / L>L_{0,05, n}\right\} \quad$ sehingga $\quad \mathrm{H}_{0}$

diterima.Ini berarti masing-masing sampel berasal dari populasi yang berdistribusi normal.

Tabel 4. Hasil Uji Homogenitas Kemampuan Awal

\begin{tabular}{|l|l|l|l|}
\hline Sampel & $\mathrm{K}$ & $\chi^{2}{ }_{\text {obs }}$ & $\chi^{2}{ }_{0,05 ; 2}$ \\
\hline Kelas & 3 & 0,058569 & 5,991 \\
\hline
\end{tabular}

Berdasarkan tabel di atas, karena $\chi_{o b s}^{2}>\chi_{0,05 ; 2}^{2}$ maka $\mathrm{H}_{0}$ diterima. Ini berarti variansi-variansi dari tiga populasi homogen.
Hasil perhitungan analisis variansi dua jalan sel tak sama dengan tingkat signifikansi 0,05 disajikan pada Tabel 5 berikut:

Tabel 5. Rangkuman Analisis Variansi Dua Jalan Sel Tak Sama

\begin{tabular}{|l|c|c|c|c|}
\hline \multicolumn{1}{|c|}{ Sumber } & JK & Dk & RK & Fobs \\
\hline Model Pembelajaran(A) & $11.517,96$ & 2 & $5.258,98$ & 27,78 \\
\hline Kedisiplinan (B) & $17.433,86$ & 2 & $8.216,93$ & 43,41 \\
\hline Interaksi (AB) & 876,74 & 4 & 212,18 & 1,12 \\
\hline Galat & $56.568,48$ & 273 & 189,29 & \\
\hline
\end{tabular}

Berdasarkan Tabel 5 diperoleh :

a) Terdapat perbedaan efek antara model pembelajaran ATI dengan pendekatan CTL, ATI, dan konvensional terhadap prestasi belajar mahasiswa.

b) Pada kedisiplinan belajar tinggi, sedang dan rendah memberikan 
efek yang berbeda terhadap prestasi belajar mahasiswa

c) Tidak terdapat interaksi antara model pembelajaran dan kedisiplinan belajar terhadap prestasi belajar mahasiswa.

Berdasarkan hasil analisis variansi dua jalan sel tak sama, pada baris utama A (model pembelajaran) diperoleh $\mathrm{F}_{\mathrm{a}}=$ 27,78 dan $D K_{a}=\left\{F / F>F_{0,05 ; 2 ; 273}\right\}$ $=\{F / F>3,00\}$ dengan demikian $\mathrm{F}_{\mathrm{a}} \in$ $\mathrm{DK}_{\mathrm{a}}$ sehingga $\mathrm{H}_{0 \mathrm{~A}}$ ditolak. Ini berarti terdapat perbedaan prestasi belajar matematika mahasiswa antara antara model pembelajaran ATI dengan CTL, ATI dan pendekatan konvensional. Setelah diuji komparasi ganda pasca anava pada baris yang sama dengan pendekatan Scheffe diperoleh semua $\mathrm{H}_{0}$ ditolak. Dengan memperhatikan rataan marginal model pembelajaran diperoleh rataan marginal prestasi belajar matematika mahasiswa dengan menggunakan model pembelajaran ATI dengan pendektan CTL 71,96; rataan marginal prestasi belajar mahasiswa dengan menggunakan model pembelajaran ATI 64,04; rataan marginal prestasi belajar matematika siswa dengan menggunakan model pembelajaran konvensional 57,17 dapat disimpulkan bahwa prestasi belajar matematika mahasiswa pada model pembelajaran ATI dengan pendekatan CTL lebih baik daripada prestasi belajar matematika mahasiswa tipe ATI, prestasi belajar matematika mahasiswa pada model pembelajaran ATI dengan pendekatan CTL lebih baik daripada prestasi belajar matematika mahasiswa pada model pembelajaran konvensional sedangkan prestasi belajar matematika mahasiswa pada model pembelajaran ATI lebih baik daripada prestasi belajar matematika mahasiswa pada model pembelajaran konvensional.

Hal tersebut sesuai dengan kajian teori dari Syafruddin Nurdin (dalam
Oktalia, 2012: 3) yang mengatakan bahwa secara substantif dan teoritik Aptitude Treatment Intraction (ATI) dapat diartikan sebagai suatu konsep/pendekatan yang memiliki sejumlah strategi pembelajaran yang efektif digunakan untuk individu tertentu sesuai dengan kemampuannya masing-masing. Selain itu, Hanifah dan Suhana (2012: 67) mengatakan bahwa CTL (Contextual Teaching Learning) merupakan suatu proses pembelajaran holistik yang bertujuan untuk membelajarkan peserta didik dalam memahami bahan ajar secara bermakna (meaningfull) yang berkaitan dengan konteks kehidupan nyata, baik berkaitan dengan lingkungan pribadi, agama, sosial, ekonomi maupun stuktural. Keduanya memberi gambaran bahwa ATI dengan pendekatan CTL suatu pembelajaran yang efektif yang dikaitkan dengan kehidupan nyata sehingga pembelajaran semakin bermakna sehingga dapat meningkatkan prestasi belajar siswa.

Berdasarkan hasil analisis variansi dua jalan sel tak sama, pada baris utama $\mathrm{B}$ (kedisiplinan) diperoleh $\mathrm{F}_{\mathrm{b}}=43,41$ dan $\quad D K_{b}=\left\{F / F>F_{0,05 ; 2 ; 273}\right\}$ $=\{F / F>3,00\}$ dengan demikian $\mathrm{F}_{\mathrm{b}} \in$ $\mathrm{DK}_{\mathrm{b}}$ sehingga $\mathrm{H}_{0 \mathrm{~B}}$ ditolak. Ini berarti terdapat perbedaan prestasi belajar matematika mahasiswa dengan kedisiplinan tinggi, kedisiplinan sedang dan kedisiplinan rendah. Setelah diuji komparasi ganda pasca anava pada baris yang sama dengan pendekatan Scheffe diperoleh

$F_{.1-.2}=52,447>\mathrm{F}_{\text {obs }} \quad ; \quad F_{.1-.3}=$ $90,928>\mathrm{F}_{\text {obs }} ; F_{.2-.3}=8,331>\mathrm{F}_{\text {obs }}$ sehingga semua $\mathrm{H}_{0}$ ditolak. Dengan memperhatikan rataan marginal kedisiplinan diperoleh rataan marginal prestasi belajar matematika dengan kedisiplinan tinggi 75,64 ; rataan marginal kedisiplinan diperoleh rataan marginal prestasi belajar matematika 
dengan kedisiplinan sedang 62,21; rataan marginal kedisiplinan diperoleh rataan marginal prestasi belajar matematika dengan kedisiplinan rendah 56,80 dapat disimpulkan bahwa prestasi belajar matematika dengan kedisiplinan tinggi lebih baik daripada prestasi belajar matematika dengan kedisiplinan sedang; prestasi belajar matematika dengan kedisiplinan tinggi lebih baik daripada prestasi belajar matematika dengan kedisiplinan rendah dan prestasi belajar matematika dengan kedisiplinan sedang lebih baik daripada prestasi belajar matematika dengan kedisiplinan rendah.

Hal tersebut sesuai dengan teori Tu'u (2004:32) yang menyebutkan bahwa disiplin muncul karena adanya kesadaran batin dan iman kepercayaan bahwa yang dilakukan itu baik dan bermanfaat bagi diri dan lingkungan. Sedangkan menurut Sinungan (Amriany, Probowati, dan Atmadji, 2004) disiplin adalah suatu sikap, tingkah laku atau perbuatan yang sesuai dengan peraturan, baik yang tertulis maupun tidak. Kedua teori kedisiplinan ini akan terbentuk dengan baik jika seseorang mempunyai kedisiplinan tinggi. Kedisiplinan ini bisa berupa disiplin dalam belajar, sikap atau disiplin dalam prinsip yang positif. Hal ini juga sesuai dengan penelitian Safitri (2012) yang mememberikan hasil bahwa kedisiplinan berpengaruh terhadap prestasi belajar matematika dengan diperolehnya nilai $t_{\text {hitung }}>t_{\text {tabel }}$ $(3,172>2,023)$ dan $\rho$-value $<0,05$ $(0,003<0,05)$. Ini menunjukkan bahwa kedisiplinan tinggi, sedang maupun rendah dapat mempengaruhi tingkat prestasi siswa.

Hasil anava dua jalan dengan sel tak sama diperoleh $\mathrm{F}_{\mathrm{ab}}=1,12 D K_{a b}=$ $\left\{F / F>F_{0,05 ; 4 ; 273}\right\}=\{F / F>2,37\}$

dengan demikian $\mathrm{F}_{\mathrm{ab}} \notin \mathrm{DK}_{\mathrm{ab}}$ sehingga $\mathrm{H}_{0 \mathrm{AB}}$ diterima ini berarti tidak ada interaksi penggunaan model pembelajaran dengan kedisiplinan belajar. Karena $\mathrm{H}_{0 \mathrm{AB}}$ diterima maka tidak dilakukan uji lanjut pasca anava antara sel pada baris yang sama dan antar sel pada kolom yang sama dengan menggunakan metode Scheffe'. Ini berarti pada masing-masing kedisiplinan baik kedisiplinan tinggi, sedang dan rendah prestasi belajar matematika mahasiswa pada model pembelajaran ATI dengan pendekatan CTL lebih baik daripada prestasi belajar matematika mahasiswa ATI, prestasi belajar matematika siswa pada model pembelajaran ATI lebih baik daripada prestasi belajar matematika mahasiswa pada model pembelajaran konvensional sedangkan prestasi belajar matematika mahasiswa pada model pembelajaran lebih baik daripada prestasi belajar matematika mahasiswa pada model pembelajaran konvensional.

\section{KESIMPULAN DAN SARAN}

Berdasarkan hasil penelitian di atas maka didapat beberapa kesimpulan yaitu :

1. Prestasi belajar mahasiswa dengan model pembelajaran ATI dengan pendekatan CTL lebih baik dari pada mahasiswa yang dikenai dengan model Pembelajaran ATI, dan model pembelajaran ATI dengan pendekatan CTL prestasi belajarnya lebih baik daripada model pembelajaran konvensional, sedangkan model pembelajaran ATI memberikan prestasi belajar yang lebih baik daripada model pembelajaran konvensional.

2. Mahasiswa dengan kedisiplinan tinggi mempunyai prestasi belajar lebih baik dibandingkan dengan mahasiswa yang mempunyai kedisiplinan belajar sedang. Selain itu, mahasiswa dengan kedisiplinan belajar tinggi berbeda prestasi 
belajarnya dengan mahasiswa yang mempunyai kedisiplinan belajar rendah, sedangkan mahasiswa dengan kedisiplinan belajar sedang lebih baik dari pada mahasiswa dengan kedisiplinan belajar rendah

3. Pada masing-masing kedisiplinan belajar, model pembelajaran ATI dengan pendekatan CTL lebih baik daripada model pembelajaran ATI dan konvensional, dan model ATI lebih baik daripada model konvensional, tetapi pada kedisiplinan sedang model ATI sama dengan model konvensional.

4. Pada masing-masing model pembelajaran, kedisiplinan belajar tinggi lebih baik daripada kedisiplinan sedang dan rendah, sedangkan kedisiplinan sedang lebih baik daripada kedisiplinan rendah, tetapi model ATI kedisiplinan sedang sama dengan kedisiplinan rendah.

Saran dalam penelitian ini adalah hasil penelitian ini hendaknya dapat menjadi pertimbangan mengenai pentingnya penggunaan model pembelajaran ATI dalam menyampaikan materi agar dapat diterima mahasiswa lebih mudah, sehingga dapat meningkatkan prestasi belajar mahasiswa. Selain itu, dalam usaha meningkatkan prestasi belajar siswa, hendaknya pendidik dapat mengimplementasikan pembelajaran matematika dengan metode-metode pembelajaran yang bervariasi.

\section{DAFTAR PUSTAKA}

Amriany, F., Probowati, Y., \& Atmadji G. 2004. Iklim Organisasi yang Kondusif Meningkatkan Kedisiplinan Kerja. Anima. Indonesian Psychological Journal. Vol. 19, No. 2, hal 179 $-193$.
Budiyono. 2009. Statistika untuk Penelitian. Surakarta: UNS Press

Caspin, O. 2004. One size does not fil all: aptitudesx treatment intraction (ATI) as a conceptual framework for complementary and alternative medicine outcome research. The Journal of Alternative and Complementary Medicine. Vol. 10, No. 3.

Hanifah \& Suhana, C. 2012. Konsep Strategi Pembelajaran. Bandung: Refika Aditama

Isjoni. 2011. Pembelajaran Kooperatif. Yogyakarta: Pustaka Pelajar

Kasihani, E. S. 2003. Pengajaran dan Pembelajaran Kontekstual. Makalah disajikan dalam Penataran Terintegrasi. Malang: Universitas Negeri Malang.

Nugroho, A. G. 2017. Eksperimentasi Strategi Pembelajaran Matematika Berbasis Masalah (Problem Solving) Dan Kontekstual (Contextual Teaching And Learning) Ditinjau Dari Gaya Belajar Siswa Di SMPN 1 Martapura. Jurnal Pendidikan Matematika. Vol. 2, No. 2, Hal 59-82.

Oktalia, N. L. 2012. Pengaruh model pembelajaran ATI (aptitude treatment interaction) terhadap hasil belajar IPA kelas V SD Negeri 11 Malaya. (http://ejournal.undiksha.ac.id/i ndex.php/ijpgsd/article/downloa $d / 829 / 72$, Diunduh 15 November 2016)

Safitri, D. 2012. Pengaruh Kedisiplinan dan Minat Belajar terhadap Prestasi Belajar Matematika Siswa Kelas $V \quad S D$ Muhammadiyah 3 Surakarta (Doctoral dissertation, 
ISSN 2089-8703 (Print) Vol. 7, No. 1 (2018)

ISSN 2442-5419 (Online)

Universitas Muhammadiyah Surakarta).

Setiani, N. 2013. Upaya Meningkatkan Prestasi Belajar Akuntansi Dengan Menerapkan Model Pembelajaran Aptitude Treatment Interaction (ATI). Jupe-Jurnal Pendidikan Ekonomi. Vol. 1, No. 2.

Susanti, V. D. 2013. Efektivitas Model Pembelajaran Group Investigation dan TAI terhadap Prestasi Belajar Matematika Ditinjau dari Motivasi Belajar pada Pokok Bahasan Himpunan Siswa Kelas VII SMP Negeri 2 Geger. JIPM (Jurnal Ilmiah Pendidikan Matematika). Vol. 2, No. 1.

Tu'u, T. 2004. Peran Disiplin dan Perilaku Prestasi Siswa. Jakarta: Gramedia Grasindo. 